\title{
Multivalence and Relevance of the Myth of Don Quixote
}

Dr. Mala Shikha ${ }^{1 *}$

\author{
${ }^{1}$ Assistant Professor in the Department of Spanish Studies, Doon University, Dehradun, India
}

DOI: $10.36348 /$ sijll.2022.v05i01.004 $\quad$ | Received: 09.12.2021 | Accepted: 22.01 .2022 | Published: 27.01 .2022

*Corresponding author: Dr. Mala Shikha

Assistant Professor in the Department of Spanish Studies, Doon University, Dehradun, India

\section{Abstract}

Cervantes published the two volumes of his masterpiece Don Quixote in early 17th century that came to be known as the first modern novel as well as a precursor to the postmodern novel. This book is considered as a canon in Western literary tradition and is one of the most translated works. The novel has the dichotomy of ideal and real at its core, however, it deals with a multitude of themes through its complex narrative. This metafictional text that continues to inspire its readers even today, questions the definition of authorship as well as readership. It holds a special relevance in every age since the publication of its first volume in 1605, nevertheless, for varied reasons. In the present work, a detailed study is done to understand the multivalence and relevance of the myth of Don Quixote in different ages that are characterised by their distinct epistemic beliefs.

Keywords: Cervantes, Don Quixote, novel, canon, multivalence, relevance.

Copyright () 2022 The Author(s): This is an open-access article distributed under the terms of the Creative Commons Attribution 4.0 International License (CC BY-NC 4.0) which permits unrestricted use, distribution, and reproduction in any medium for non-commercial use provided the original author and source are credited.

\section{INTRODUCTION}

The Ingenious Hidalgo Don Quixote de la Mancha, originally known as El Ingenioso Hidalgo Don Quijote de la Mancha, written by Miguel de Cervantes Saavedra continues to be a very fascinating subject for reading and research in the literary world, even after more than 400 years of the appearance of its first volume in 1605 and the second in 1615 .

Some believe, as Cervantes alludes in the prologue of the first part of his book, that it was in prison where the author sowed the seeds of his literary genius and began to write this masterpiece which, at first glance, is a novel about the adventures of a knighterrant with little sanity but with a big heart. Many scholars believe that Cervantes can be termed as a survivor. He survives the period of Golden Age in Spain, a period that witnesses multiple problems, a period that experiences various epistemological changes, as well as socio-cultural and economic crisis. In his great literary repertoire Cervantes carries this experience of survival that is reflected in his style of writing, in the typical language of his texts, in the themes he identifies and develops, in the characters he draws and in his unique way of narrating the stories. He witnesses the typical and specific social conditions of his homeland during 16th and 17th centuries. In the first half of his life he witnesses the rise of Spain after the Reconquest as the most powerful empire in the Western world under the reign of Charles $\mathrm{V}$ during 1519 to 1556, and its fall later during the reign of Philip II, especially due to many military conflicts such as the defeat of the Spanish Armada in 1588. He is also a witness to the Spanish Inquisition and the increasing influence of censorship during the reign of Philip II under the Tribunal of the Holy Office of the Inquisition in 17 th century. However, he survives. He survives as the Church and the Inquisition, both were more concerned with rooting out heresy than literary creativity. Not only does he survive, but he also takes on a great literary aspiration in this harsh era that has Don Quixote as its axis and that continues to draw us closer to it, even today. This great literary collection beckons us for its transcendental theme, for its multilayered narrative, for its multivalence, for the nuances it contains and for its subversive criticism of the status quo.

\section{Cervantes, a master of his craft}

During his life (1547-1616) Cervantes dealt with diverse topics in his works that had deep value for the human race. His works are very relevant in modern times because they discuss the issues that preoccupy our minds today. At the same time his works highlight the situation of the society from the period of their 
Mala Shikha., Sch Int J Linguist Lit, Jan, 2022; 5(1): 32-37

publication. In Don Quixote Cervantes intersperses and weaves normal characters with phenomenal undertones, especially the protagonist Don Quixote who, despite his frail physical appearance, has a very strong and complex imagination. The evolution of the characters stands out in the work, of which we have already mentioned that they carry various hues in their own profiles, and thus they create an environment of multivalence in the novel. Fernando Rico, a Spanish philologist and Cervantista opines in his own edition of the book published by Punto de Lectura in Madrid, "Don Quixote is a book thought without haste and written (or better perhaps, narrated) in rush." (2007, p. 1205) Undoubtedly, it is a well thought out book as the first volume of the book was published in 1605 and it was only after ten years that the second volume was published in 1615. It is a well thought out book with a subversive argument, both in its narrative and theme as well as in its literary language. The omniscient author and the omnipotent reader, the varied themes, the nuanced characters and the simultaneous presence of cultured language and language full of proverbs make it a well thought out book.

Juan Manuel Lucía, President of the Association of Cervantistas in Madrid believes that Don Quixote holds multiple keys to understanding humanity and the complexity of human being, which is why it is worth reading, even today. The same is the opinion of Mexican writer Elena Poniatowska, the 2013 Cervantes Prize winner, who recalls the values and ideals of a character who intends to change the world by challenging the status quo. She underscores that the adventure of Don Quixote is an internal journey that encourages us to think how we can transform reality from our worldview. Don Quixote's worldview was obviously idealistic. For Poniatowska he is an indelible and unattainable character who is a great figure of universal literature. The journeys undertaken by the protagonist Don Quixote with his squire Sancho Panza take the readers on a path, perhaps completely unknown, to make some very personal journeys and at the end of the narrative there are many internal changes that the readers feel they have experienced.

Juan Manuel Bonet, the director of the Cervantes Institute in Paris, underlines the deep imprint left by Cervantes' work Don Quixote and its profound influence on literature as well as on other manifestations of art that follow it. For Bonet, there is something very "Cervantine" which not only many Spanish but also Latin American writers relate themselves with. Its influence is not only observed in literature. Picasso made his own version of Don Quixote; let alone the countless musicals or film versions. There is humanity as well as irony in Cervantes that are reflected in Don Quixote. It is one of those classics that are still alive according to Bonet. It is evident that Cervantes uses humor to highlight the situation of the erstwhile society and puts us alongside his magnificent characters and their adventurous experiences throughout the plot.

In Real Academia Española's version of the book, Marqués de Grimaldi described Don Quixote as the glory of Spanish Ingenuity and precious deposit of the legacy and spirit of Castilian Language. (2004, p. IX) In the same version, for Mario Vargas Llosa, "it is an image". (2004, p. XIII). It is important to mention here what Francisco Rico propounds in his edition of the book.

Antes que nada, Don Quijote de la Mancha, la inmortal novela de Cervantes, es una imagen: la de un hidalgo cincuentón, embutido en una armadura anacrónica y tan esquelético como su caballo, que, acompañado por un campesino basto y gordinflón montado en un asno, que hace las veces de escudero, recorre las llanuras de la Mancha, heladas en invierno y cadentes en verano, en busca de aventuras. (2007, p. 1137)

First of all, Don Quixote de la Mancha, Cervantes' immortal novel, is an image: that of a fifty-year-old hidalgo, encased in anachronistic armour and as skeletal as his horse, accompanied by a rough and chubby peasant mounted on a donkey who acts as a squire, who travels the plains of La Mancha, freezing cold in winter and hot in summer, in search of adventure.

\section{The Myth of Don Quixote}

In due course of time the character Don Quixote has become a myth, including Don Juan and La Celestina in Spanish culture. The meaning of this myth of Don Quixote varies in each epoch and depends on the epistemology of that period. Since there are multiple ways to interpret the theme of this work, some consider that it is a satire of chivalric novels whereas others read it as a book of adventures of a knight-errant accompanied by his squire. This book is also read as some trips that our author, Cervantes, would have undertaken in his own life. However, defining the central theme of this work is a rhetorical question due to the multiplicity of themes found in this book, which is considered as the pillar of the modern novel or rather, the antecedent of the postmodern novel. It has a universal meaning because it is a macrocosm of its time, its history, its culture and its society; at the same time it is also a human microcosm where characters such as Don Quixote and Sancho Panza are perfectly crafted by the great Spanish author, Miguel de Cervantes Saavedra. Francisco Rico highlights in his edition of the book,

Incluso los personajes dibujados con unos colores llevan expresa o implícita una contrafigura de signo opuesto.

La dualidad o multiplicidad de modos de ser no está solo en las actitudes y conductas de cada personaje, sino asimismo en la manera en que Cervantes confronta a unos con otros. En particular, la narración persevera en recogerlas distintas perspectivas con que los participantes contemplan una misma escena, para que 
Mala Shikha., Sch Int J Linguist Lit, Jan, 2022; 5(1): 32-37

todas se maticen mutuamente y sean tomadas en cuenta por el lector. (2007, p. 1137)

Even the characters drawn with unique tones, explicitly or implicitly, carry a counter-figure with an opposite sign.

The duality or multiplicity of ways of being is not only in the attitude and behaviour of each character, but also in the way in which Cervantes makes them interact with each other. Particularly, the narration strives to emphasise different perspectives with which the participants contemplate the same scene, so that they all influence each other and they are noted by the reader.

According to the hermeneutics, a detailed reading of the text is required so that the microtextual aspects interspersed throughout the plot that correspond to the macrotextual design of the work are analysed adeptly. From the synchronic perspective of historiography, the novel gives us a social and historical panorama where customs, religion, morality, thought, ideological tendencies, etc., are manifested from the time of Cervantes. The author develops characters as complicated as Don Quixote and Sancho Panza, with their unique psychological framework and their passionate and emotional charge that embody and represent doubts, embarrassments, uncertainties, frustrations, disappointments, ambitions, anxieties, pride, impertinence, reflection and thoughtlessness, ideals, all the commonalities and all the contradictions, just as we human beings are in our daily lives. Our author perpetually plays with both, themes and genre, in this masterpiece. As we have already said, characters that seem very normal carry many nuances in their own profiles. It continues to be debated for centuries whether the protagonist is a hero or an antihero or even a madman. The book contains many contrasts. The dichotomy of the ideal and the real exists throughout the plot. There is a knight-errant who believes in a fantastic world of heroes and knights and their bizarre adventures, but lives in an environment of peasants, slaves, prostitutes and their misery. Nevertheless, by the power and force of his imagination he is able to question the social order and provide social agency to many marginalised characters in the novel. His imagination, which seems to some to be a great madness, has a voice of resistance and is in favour of freedom, although he shows it through his burlesque adventures. Francisco Rico gives his opinion on chivalry, the inspiration for our protagonist Don Quixote de la Mancha.

Ese personaje del roman courtois, de la novela francesa medieval, es una diáfana sublimación del caballero de la realidad, no tan asiduo a los campos de batalla como a los juegos del amor y la guerra, y a la vez lo guía y lo moldea en la realidad, invitándole a unas estilizadas maneras de comportamiento y mostrándole una teoría que le basta asumir parcialmente para sentirse por entero justificado en la práctica, mucho menos intrépida y eminente. La literatura arranca de la realidad y revierte sobre la realidad, en ambos casos para idealizarla. El caballero se mira en el retrato y se ve tan favorecido que se afana por parecérsele o acaba creyendo que se le parece (Rico, 2007, p. 1118-1119).

That character from the roman courtois, from the medieval French novel, is a diaphanous sublimation of the knight of reality, not so assiduous on the battlefields as in the games of love and war, and at the same time guides and moulds him in the reality, inviting him to some stylised ways of behaving and showing him a theory that he only has to partially assume to feel entirely justified in practice, much less intrepid and eminent. Literature starts from reality and reverts to reality, in both cases to idealise it. The gentleman looks at himself in the portrait and sees himself so favoured that he strives to resemble him or ends up believing that he resembles him.

Rico also points out in the same context, that the knight creates an artificial environment in which he reconstructs himself as a bookish character. (p. 1120) Therefore, the power of this character who is capable of modifying his environment, reality into fantasy to restore his ideals of freedom, must always be taken into account.

\section{Reception, Multivalence and Relevance}

As has been mentioned, the novel appeared in two volumes, the first in 1605 and the second in 1615, contains thousands of pages in each version and there are thousands of versions today thanks to the commemorations of the IV Centenary of the publication of the first volume of this great book in 2005. Don Quixote offers a fairly simple and well-constructed "story" of a nobleman from La Mancha who reads many chivalric books and that results in the loss of "reason". As a result of this "madness" the hidalgo undertakes some adventurous journeys as a knighterrant accompanied by a "squire" named Sancho Panza who, in reality, is a peasant looking for a better life. At that time the word "history" referred to the narrative containing the verisimilitude that distinguished it from poetry that was considered fictitious and lacked the truth.

When this book was first published in 1605 it received a great reception and the author also garnered instant fame but not in a financial sense nor did it become an immediate "classic" in comparison to the works of his contemporaries such as Lope de Vega, Francisco de Quevedo, Pedro Calderón de la Barca etc. Cervantes lived his whole life in a humble and poor condition despite receiving so much success for the two volumes of Don Quixote and his other notable works such as Novelas Ejemplares (1613) etc. Within a few years of the publication of the first volume of Don Quixote, translations of this book appeared in many other languages that gave it an immense international fame. After the Bible, this novel is the only book that has the fame of being the most translated book in the world's most spoken languages. A book appeared 
Mala Shikha., Sch Int J Linguist Lit, Jan, 2022; 5(1): 32-37

written by a certain Avellaneda in 1614 entitled Segundo tomo del Ingenioso Hidalgo Don Quijote de la Mancha (Second volume of the Ingenious Hidalgo Don Quixote de la Mancha) but it came to be known as the apocryphal Quixote. According to some theories that exist regarding this apocryphal book that it was one of Cervantes' enemies, the ones he had during his military or literary life, who wrote this book to take revenge on him. Thanks to this apocryphal book, Cervantes published the second volume of his famous book in the following year, in 1615, eliminating the doubt that whether a second volume of his book would be published at all.

It is worth mentioning that there is a great debate about the authorship of this book, but the general opinion accepts Cervantes as the voice of the narrator who is omnipresent in the book and also as the original author of the novel in question, that is, Don Quixote.

What else is worth emphasising about this major work is its great reception and the variety of interpretations in subsequent centuries. It is the most quoted and translated work after the Bible. When the first volume appeared in 1605 and the second in 1615, it was characterised for its satirical and burlesque nature, almost an attack on the tradition of chivalric books, with its carnivalesque characters especially Don Quixote and Sancho Panza who moved its readers due to its comical effect during Baroque in 17th century. It achieved instant publishing success and many editions of this book went out. There were many translations in various languages such as in English by Thomas Shelton which appeared in 1612 and in French by César Oudin in 1614 of the first part of Don Quixote. The Italian version appeared in 1622 and in the Americas, within a few months of its first publication. It became a part of popular culture and its characters appeared at festivals and carnivals, and it gradually became a part of universal folklore. Many texts appeared soon after its publication that seemed to have a connection to it, such as in 17 th century a version of it by Guillén de Castro appeared in 1610, the lost comedy by Calderón de la Barca in 1634, some interludes, the apocryphal Quixote by Alonso Fernández de Avellaneda and the second part of Don Quixote published in 1615 by Cervantes himself, which has constant allusions to the reception of Don Quixote I and also refers to the first volume on many occasions.

It is worth underlining what Anthony J. Close says in the chapter "Mguel de Cervantes" included in The Cambridge History of Spanish Literature that is edited by David T. Gies,

Despite scores of imitations of particular incidents in it, or allusions to it, in subsequent literature, the only Spanish writers who systematically treat it as a model of fictional prose-narrative are Avellaneda and Alonso Jerónimo de Salas Barbadillo (1681-1635). In this respect, it would not become a canonical paradigm until the eighteenth century. (2009, p. 201)

Cervantes is believed to have been anticanonical and that he scoffed at works that were didactic. He wanted to keep his book unpretentious, as the result he contributed to it by not reaching the level of a "classic" during his time. However, in the next century, with the arrival of neoclassical and enlightenment values in 18th century, the satirical sense was valued as if it were a criticism of the customs and vices and defects of previous centuries. It was at this time that it became a "classic" and began to appear in literary history. It was read with a nationalist approach at this time that witnessed colossal epistemological changes and that was characterised by the question of freedom. What is very interesting at this time is a great interest in the life of Cervantes such as the work Life of Cervantes by Mayans and Siscar published during this period in 1738 .

The 19th century is marked with the romantic interpretation and positivist erudition of Don Quixote. German romantics such as Heine, Schlegel and Schelling saw it as a symbol of a tragic hero who fought for the unattainable ideal against the ugly and disgusting reality of his time but who has plausibility in any age and society. During Romanticism, the protagonist becomes a mythical symbol that embodies all the values of a romantic hero, for which Cervantes expressed ideas about the relationship of the human spirit with reality and the nature of the history of Spain. The romantics idealise Don Quixote and deny the satirical purpose of the novel. Russian writer Fyodor Dostoyevsky compares him to Jesus Christ. British intellectual W. H. Auden sees him as "the ironic hero" in his essay with the same title. On many occasions this romantic reception reaches an esoteric level, for example the interpretation of Juan Valera in Spain. In the second half of the 19th century, which is marked by positivist erudition, the term "Cervantismo" arises and as a result the "Cervantistas", for example, Menéndez Pelayo etc. Anthony J. Close emotions again in The Cambridge History of Spanish Literature that,

Around 1800, the Neoclassical interpretation of Don Quijote was overturned by the German Romantic movement, which took it as a model of the "Romantic" par excellence, the novel. The Romantics found in Don Quijote poetic grandeur on the level of Shakespeare's , and, more specifically, a bitter-sweet attitude to medieval chivalry, philosophic profundity, a rich polyphony of tones and styles, the ironic sense of the gap between Ideal and Real, and the artist's playful detachment from his own creation. They utterly rejected the treatment of it as a work of coarse comicality suitable for "the digestion hour after dinner," in Freidrich Shlegel's apt phrase. (2009, p. 202)

In many other countries, one begins to recover the relevance of Don Quixote and see it as the seed of 
the modern novel. This time is also marked with its influence on many artists in almost all cultures such as Dickens in England, Flaubert in France, Mark Twain in the United States, Alessandro Manzoni in Italy and Pushkin in Russia, Juan Montalvo in Ecuador.

In the 20th century the romantic tradition continues. What stands out the most at this time is the duality of the two main characters, Don Quixote and Sancho Panza who act as a metaphor for the contradictory and inseparable components of human genius. The Generation of '98 in Spain, that included Unamuno, Maeztu, Azorín, saw it as an example to achieve regeneration and recover the country from decandence. Anthony J. Close goes on saying,

It is a commonplace about literary masterpieces that they have an inexhaustible capacity for self renewal. In Don Quixote's case, this cliché is strikingly confirmed by historical fact; it has somehow managed to tilt a different facet to each successive age, in which the age can recognize the reflection of its own features. For example, the eighteenth century loved it for Enlightenment reasons. The German Romantics recreate it in their own image. So the process of recreation has continued until Post Modernism which, as we shall see, looks at it through a Bakhtinian lens. (p. 203)

In each period a new, more nuanced dialogue appears between this novel and the intellectuals of a particular age.

Nil Santiáñez studies the modernist character in this novel carefully and mentions it in the chapter "Great masters of Spanish Literature" in The Cambridge History of Spanish Literature,

A Modernism of longue durée: as regards the Modernist prose in its time span, it can be said that it is born with Don Quijote $(1605,1615)$. The main traits and techniques of Don Quijote are obviously modernist, for instance its overlapping of narrative voices, its epistemological relativism, metaliterature, the importance of the act of reading in the novel, and the embodiment of literature in Don Quijote and other characters. The Modernist prose inaugurated by Don Quijote continues with Fray Gerundio de Campazas (1758, 1768), turn-of-the-century Modernism, the avant-garde, and with the experimental prose that, in the post-Civil War period, was cultivated primarily following the publication Tiempo de Silencio ("Time of Silence," 1962). (p. 481-482).

Anthony J. Close also mentions it,

That at least is how his novel has been interpreted in the twentieth century, from Américo Castro ( $E l$ pensamiento de Cervantes), to Leo Spitzer to Carlos Fuentes; and the interpretation has acquired a new lease of life in the postmodernist age, thanks to the pervasive influence of the "dialogic" theory of Bakhtin. It draws strength from the notorious "metafictionality" of Don
Quijote: that is, Cervantes' practice of alluding within a novel to its own fictional status, which includes representing the process of creating, consuming, and criticizing fiction. (p. 216).

Ortega y Gasset published his critical review of the book as Meditaciones del Quijote (Meditations on Quixote) in 1914 and claimed its value as a modern novel. El pensamiento de Cervantes (The Thought of Cervantes) written by Américo Castro and published in 1925 begins to look at different possibilities and meanings in this book. Many modernists as Rubén Darío, Juan Ramón Jiménez and those of the Generation of ' 27 acknowledged it as one of their favourite books. Also noteworthy are the illustrations made by Pablo Picasso and Salvador Dalí in 20th century.

In the contemporary period, from the second half of the 20th century to the present day, renewed criticisms arise, that return to the humorous interpretations of the journeys of this knight-errant, but they maintain its symbolic value. For modern critics, Don Quixote is a relic from the past, in its own time and even today. There are signs and symbols in this book for modern readers that provide them with a space to make their own interpretations. In South America there appears a story by Argentine author Jorge Luis Borges entitled "Pierre Menard, author of Quixote" (1962) that reflects on the complicated issue of authorship in this book. In recent times Anthony J. Close, E. C. Riley, John Jay Allan, Francisco Rico, Martin de Riquer stand out as "Cervantistas". There are a number of criticisms written by these intellectuals on varied themes within the novel. "The Cervantes Society of America" was founded in 1978, launching a journal called Cervantes. Salman Rushdie published his fourteenth novel Quichotte in 2019, which is an ode to Cervantes' Quixote but it is, at the same time, a metafiction contextualised in current times. The focus at present is to convey the various nuances of an interpretation of this novel and to appreciate the profound multivalence within the narrative.

\section{Concluding Remarks}

The reader of this great literary work, indeed, becomes like the omnipotent god due to the issue of the relationship between illusion and reality. The reader is the most powerful one as the spectator in the Baroque painting "Las Meninas" (1656) by Diego Velázquez and the reader in the Spanish Golden Age drama La Vida es Sueño (1636) by Pedro Calderon de la Barca. By taking us to the world of chivalric texts, the plot in this novel takes us to a humorous extreme, the possibilities of deceiving us and making us believe that Don Quixote did exist through these journeys of the protagonist with his squire that contain a "quixotic spirit". Cervantes evokes his readers in the prologue by the first words of this book "Idle reader" but due to his creative reflection throughout the novel the reader is no 
longer "idle". Instead, he becomes a character in the plot who now lives in a Borgesian world with those labyrinths that lead to so many interpretations of a single novel. Much later, Cervantes refers to the reader as "enlightened reader" in the prologue of the second volume of the novel. One can imagine that when a reader has so many possibilities to make various interpretations of a text then how many interpretations there must be of the innumerable readers of this masterpiece. Many erudite scholars believe that what we refer to as a Borgesian world in Don Quixote is originally a Cervantes' theme, which Borges renewed much later and put his own stamp on it. The reader is no longer what he was when he read these first words written by Cervantes. He acquires a new postmodern identity with constant intertextuality and deconstructs the modern myth of Don Quixote that he had found in previous centuries to propose new criticisms of this "history/story". He gets into the hermeneutics of the romances to highlight the unstable referentials of the lexicon within the novel and analyses them on his own, in his own terms to arrive at new results. Francisco Rico sums it up in a very cohesive way that Cervantes offers us all the possibilities at once. (p. 1137)

\section{ACKNOWLEDGEMENT}

The author acknowledges the academic support received from Professor Rajiv Saxena, CSPILAS, SLL\&CS, Jawaharlal Nehru University.

Declaration of conflicting interests: The author declares that there is no conflict of interest.
Note: The author has carried out the translation of texts from Spanish to English in the article.

\section{REFERENCES}

- Borges, J. L. (2005). "Pierre Menard, autor del Quijote". Ficciones: Obras Completas, Buenos Aires: Emecé.

- Cervantes, Miguel de S. (2004). Don Quixote de la Mancha, Madrid, Real Academia Española: Asociación de academia de la lengua española.

- Maravall, J. A. (1986). Culture of the Baroque: Analysis of a Historical Structure, Translated by Terry Cochran, Manchester: Manchester University Press.

- Ortega., \& Gasset, J. (2005). Meditaciones del Quijote, Madrid: Cátedra.

- Piña, M. C. (2016, April 22). Cervantes, o la eterna modernidad del Quijote. http://m.es.rfi.fr/cultura/20160422-cervantes-o-laeterna-modernidad-del-quijote. Accessed on 24 April 2016.

- Quint, D. (2005). Cervantes' novel of modern times: a new reading of Don Quixote, Princeton NJ: New University Press.

- $\quad$ Rico, F. (ed.). (2007). Don Quijote de la Mancha / Miguel de Cervantes, Madrid: Punto de Lectura.

- Gies, T. D. (ed.). (2008). The Cambridge History of Spanish Literature, Cambridge: Cambridge University Press. 